UNIO - EU Law Journal. Vol. 5, No. 1, January 2019, pp 54-67.

®2019 Centre of Studies in European Union Law

School of Law - University of Minho

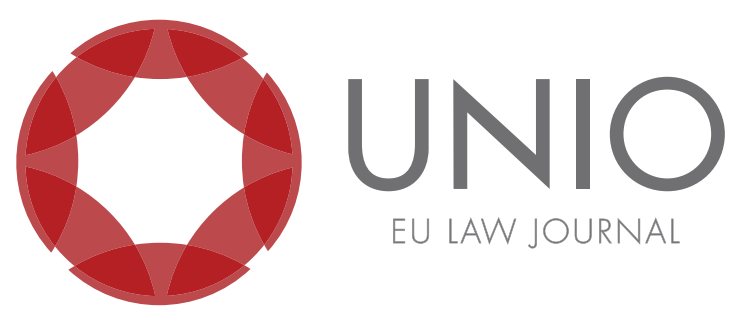

\title{
Sharing economy, competition and regulation: the case of Uber in the case-law of the Court of Justice of the European Union
}

\author{
Patrícia Fragoso Martins*
}

ABSTRACT: This article deals with the judgments of the Court of Justice of the European Union on the Uber cases, highlighting some implications of those judgments in the fields of competition and regulation. Uber is widely referred to as the paramount example of sharing economy. With this background, there has been intense debate on the need for a new regulatory framework and on the avenues left open by competition law. Although not addressing said issues directly, by considering Uber a carriage company, and not merely an electronic platform, the Court of Justice has contributed to "thicken the plot" on both these fronts.

KEYWORDS: sharing economy - competition - Uber - transport service - information society.

\footnotetext{
* Professor at the School of Law of the Catholic University of Portugal.
} 


\section{Introduction: Uber as sharing economy}

Uber needs no introductions. It is one of the most famous electronic platforms to have been created in the last decade and it is said to be destined to change not only the way we move in urban areas but, above all, the way we live. Founded in 2009, with headquarters in San Francisco, California, Uber was initially a ride-hailing service. Currently, it offers peer-to-peer ridesharing, taxicab hailing, food delivery, bicycle-sharing, among other services. At the moment of the writing of this article, the company has operations in 785 metropolitan areas worldwide ${ }^{1}$ and it is estimated that it has 100 million users worldwide. On $8^{\text {th }}$ Dec. 2018, Uber filed for an initial public offering and it was announced that it could be valued at more than 100 billion US dollars. $^{2}$

Even if it can be said that the emergence of new technologies always carries with it controversy and debate, Uber seems to constitute a unique case. Often referred to as a "disruptive innovator", ${ }^{3}$ it has invaded language, "uberizing" referring to a revolutionary way of not only doing business, but more broadly, of organizing communities. The meaning of the new word is twofold as it reflects both, the hesitations and critiques that Uber has given rise to and the hopes and expectations it brings with it. This new reality challenges our preconceptions and puts into question well-known structures and concepts from the past. In a short article titled "Uber somos todos", ${ }^{4}$ Luz Rodríguez argues that, in certain sense, we all are Uber. We all are Uber inasmuch as we act as consumers, who sooner or later, reach out to electronic platforms to have access to certain services (e.g., Cabify, Airbnb, Deliveroo). But above all, we are Uber because the way these platforms work is destined to affect the labour market so intensively that we all end up being affected as employees, employers and members of the community as a whole.

From an economic standpoint, Uber is often mentioned as the most prominent example of the so-called "sharing economy". Although there is no consensus on the exact scope of this concept, the advent of digital platforms has been welcomed as an alternative to consumerism and the traditional model of private and individual ownership. ${ }^{5}$ Through those platforms "individuals gained the opportunity to re-design the way in which they consume, own, and work. Instead of enabling companies to sell their goods and services, those platforms allowed peers to benefit from joint access to products and skills. There, individuals could share, barter, lend, rent, gift, and swap resources that would otherwise be underutilised". ${ }^{6}$ The European Economic and Social Committee has noted that collaborative or participatory consumption practices can apply virtually to any aspect of daily life, "such as:

- mobility (car-sharing, the rental and shared use of vehicles, including taxis, bicycles and parking places, and carpooling, which means filling empty car seats with other passengers going in the same direction),

- energy efficiency (shared use of household utensils),

\footnotetext{
${ }^{1}$ See https://www.uber.com/en-PT/cities/.

${ }^{2}$ See https:/ / www.bloomberg.com/news/articles/2018-12-08/uber-is-said-to-file-confidentially-forinitial-public-offering.

${ }^{3}$ See e.g., Scott Anthony, "Disruptive innovation: what's holding Uber Back," Harvard Business Review (June 2014), https://hbr.org/2014/06/whats-holding-uber-back.

${ }^{4}$ Luz Rodriguez, "Uber Somos Todos", InfoLibre, 06.03.2017, https://www.infolibre.es/noticias/ luces_rojas/2017/03/05/uber_somos_todos_61998_1121.html.

${ }^{5}$ See Margherita Colangelo and Mariateresa Maggiolino, "Uber: A New Challenge for Regulation and Competition Law?," Market and Competition Law Review, vol. 1, issue 2 (2017): 48.

${ }^{6}$ Ibidem, 48-49.
} 
- accommodation and areas for growing food (rental of rooms, shared housing, and urban and rural allotments),

- business (co-working or shared office space),

- communications (mobile platforms where users can buy and sell goods and services to people living in the same community),

- work (micro-tasks, biring people for specific jobs, or "bandymen", where the best bidder is given tasks ranging from hanging pictures to assembling items of furniture),

- culture bookcrossing and book bartering, and promoting cultural exchanges among young people from different countries),

- education (digital communities for learning languages),

- time and skills (time banks),

- leisure (sharing digitised content),

- finance (loans between individuals, direct loans from individuals to small and medium-sized enterprises, crowdfunding or collective financing, crowdfunding for crowdbenefits),

- tourism (dining experiences in private homes), and peer-to-peer food swapping,

- art and also markets for bartering and donating clothing and items for children, repair and recycling of objects; many other initiatives could be mentioned, but a comprehensive study of these is not the purpose of this opinion,

- promoting the use of renewable energies, where possible sharing energy surpluses through smart networks".

In this context, scholars have considered that the sharing economy may consist basically of two different business models. In the first model, market players offer goods or services through the internet, mobile apps, or both. In the second, business entities create a web platform where owners of goods or performers of services meet and conclude sharing agreements with people who want to access such goods or services. ${ }^{8}$ Whereas the first model involves two parties and one agreement between them, the second is based on a tripartite relationship involving the conclusion of several agreements. In this sense, Uberpop falls in the latter business model of the sharing economy.

The European Commission has also acknowledged the rapid emergence of a variety of collaborative economy business models across Europe, which change the way services are traditionally provided and consumed. In its "European Agenda for the Collaborative Economy", " the Commission adopted a very broad definition of the term, considering that "collaborative economy" includes "business models where

\footnotetext{
7 Opinion of the European Economic and Social Committee on "Collaborative or participatory consumption, a sustainability model for the $21^{\text {st }}$ century”, Brussels, 21 January 2014, para. 4.10. In its Opinion, the EESC further noted that "collaborative or participatory consumption (...) represents an innovative complement to a production economy in the form of a use-based economy offering economic, social and environmental benefits. It also offers a way out of the economic and financial crisis, by enabling people to exchange things for others that they need (...). Given the complexity and importance of the emergence of collaborative or participatory consumption, the relevant institutions need, on the basis of the necessary studies, to regulate the practices carried out within these forms of consumption, in order to establish the rights and responsibilities of all the stakeholders involved. Firstly, collaborative or participatory consumption can meet social needs in situations where there is no commercial interest and, secondly, it can help, as a for-profit activity, to create jobs, while complying with the rules on taxation, safety, liability, consumer protection and other essential rules". See paras. 1.3. and 1.4. See also European Parliament - Directorate-General for Internal Policies - Policy Department Structural and Cohesion Policies - Research for Tran Committee - Tourism and the Sharing Economy: Challenges and Opportunities for the EU 2015.

${ }^{8}$ See Alessio di Amato, "Uber and the Sharing Economy," The Italian Law Journal, vol. 2, No. 1 (2016): 185.

${ }^{9}$ Communication from the Commission to the European Parliament, the Council, "The European Economic and Social Committee and the Committee of the Regions: A European Agenda for the Collaborative Economy", COM(2016) 356 final, Brussels, 2.6.2016.
} 
activities are facilitated by online platforms that create an open marketplace for the temporary use of goods or services often provided by private individuals". ${ }^{10}$ According to the Commission, this collaborative economy involves three categories of actors: (i) service providers who share assets, resources, time and skills, and that can be private individuals offering services on an occasional basis or professional service providers; (ii) users of these services; and (iii) collaborative economy platforms that connect providers with users and facilitate transactions between them, also ensuring the quality of these transactions (e.g., through after-sale services, insurance services, etc). As a rule, collaborative economy transactions do not involve a change of ownership and can be carried out for profit or not for profit.

It is unclear, however, if Uber fits perfectly the new category. As is well-known, Uber cannot be considered merely a mobile application hosting several transactions occurring between consumers and drivers. The company supplies the electronic payment system, fixes the price and guarantees the price fixing system, organizes the listings, charges a fee for each transaction and issues quality and safety standards for vehicles and drivers. Scholars have, thus, argued that "Uber falls somewhere along a spectrum between purely hosting platforms and direct service providers". ${ }^{11}$

The difficulty in finding the right fit for Uber has also been felt at the juridical level, lawyers struggling to find the adequate legal answers to address the issues raised by Uber's business model. The company's strategy of entering the market first and dealing with legal compliance issues later, has led to the multiplication of lawsuits around the world pertaining to very different areas of the law - a phenomenon suggestively referred to as the "Ubergate". ${ }^{12}$ Indeed, currently, ongoing legal cases involving Uber extend to the fields of (i) Commercial law (with taxi drivers accusing Uber of unfair competition practices); (ii) Labour law (with Uber drivers claiming for labor law protection); (iii) Administrative law (having Uber been refused licensing in certain cities due to public safety concerns); (iv) Regulation (the difficulties in establishing an adequate regulatory framework for the transport activities); (v) Competition law (from the discussion of the Uber-Grab merger in Malaysia ${ }^{13}$ to the charges against Uber and Uber drivers of colluding with the objective of influencing prices); ${ }^{14}$ (vi) Tax law (mostly on VAT issues); (vii) Company law (with alleged practices of mismanagement); (viii) Intellectual Property (e.g., the Waymo case) ${ }^{15}$ and (ix) Criminal law (the cases involving sexual misconduct against employees). It is, thus, not surprising that this complex new reality has, at a certain point, reached the European Union Courts as well.

\section{Uber and competition law: information society or transport services?}

Most of the lawsuits brought against Uber involve the allegation of unfair

\footnotetext{
${ }^{10}$ See "European Agenda for the Collaborative Economy", 3.

${ }^{11}$ Margherita Colangelo and Mariateresa Maggiolino, "Uber: A New Challenge for Regulation and Competition Law?", 50.

${ }^{12}$ Alessio di Amato, "Uber and the Sharing Economy", 179.

${ }^{13}$ See https://www.umlawreview.com/lex-in-breve/relevance-of-competition-law-on-the-uber-grabmerger.

${ }^{14}$ See Spencer Meyer v Travis Kalanick, 15 Civ 9796, 2016 US Dist. See Julian Nowag, "The Uber Cartel? Uber between Labour and Competition Law", Lund Student Law Review, WP 1/2016, 5.

15 See http://fortune.com/2018/02/05/waymo-v-uber-what-you-need-to-know-about-the-high-stakesself-driving-tech-trial/.
} 
commercial practices because the company does not meet the regulatory requirements applicable to taxi operators. As someone has put it, it is argued that Uber "does not pay taxes or licensing fees; it endangers passengers; its drivers are untrained, unlicensed and uninsured or underinsured; passengers are not covered by insurance and in general, the company breaks the law" ${ }^{16}$

As a rule, national courts have found Uber in breach of domestic laws on unfair competition. Quite surprisingly, with minor exceptions, the issue of the exact legal qualification of Uber services has not been explored. ${ }^{17}$ It is undisputable, however, that in order to determine which rules should apply to Uber, it is necessary to first adjudicate on a question of legal qualification, i.e. to determine the exact nature of the services rendered by Uber. In particular, to discern whether Uber's activities should be deemed as "transport services" or "information society services".

In this respect, Uber's position is clear. The company has widely argued that it is merely an electronic platform and it does not provide any transport service. The application works in such a way as to put into contact potential drivers and potential passengers in whose relationships Uber does not participate or interfere in. Therefore, Uber is not in competition with taxi drivers or radio taxi services as it acts in a completely different market.

Due to the complexity of the issue and the lack of substantial guidance in this respect, some national courts have decided to address the Court of Justice of the European Union (CJEU). This was the case of the Nederlandstalige rechtbank van koophandel Brussel, in December 2015, of the Tribunal de Grande Instance de Lille, in July 2016, and of the German Bundesgerichtshof, in September 2017.18

Before them, in August 2015, the Juggado de lo Mercantil No. 3, of Barcelona, sent the first request to the CJEU regarding the rules to be applied to Uber. ${ }^{19}$ The facts of the case are well-known. In 2014, the Asociacion Profesional Elite Taxi brought an action seeking, inter alia, a declaration that the activities of Uber Systems Spain infringed the legislation in force amounting to misleading practices and acts of unfair competition, and an order to cease its operations. The Barcelona court noted that although Uber Spain carried out its activity in Spain, that activity was linked to an international platform, thus justifying the assessment at EU level of the actions of the company. Furthermore, in order to determine whether the practices of Uber Spain and

\footnotetext{
${ }^{16}$ Alessio di Amato, "Uber and the Sharing Economy", 180.

${ }^{17}$ By contrast, administrative courts in Berlin and Hamburg have rejected the qualification of Uber as a mere intermediary, supporting a wide interpretation of Uber as a carrier (VG Hamburg, 27 Aug 2014, 5 E 3534/14 and OVG Hamburg, 24 Sep 2014; VG Berlin, 26 Sep 2014, VG 11 L 353.14 and OVG Berlin-Brandeburg, 10 Apr 2015, OVG 1 S 96.14). See Margherita Colangelo and Mariateresa Maggiolino, "Uber: A New Challenge for Regulation and Competition Law?”, 53-54. In March 2015, the Geneva Department of Security and Economy banned Uber's services in Geneva, stating that Uber qualifies as a taxi dispatching center under Geneva Taxi law and fails to comply with the therein stated rules. See Jessica Kim Sommer, "UBER in Switzerland," Journal of European Consumer and Market Law, vol. 3 (2015): 116-118.

${ }^{18}$ The first of these cases discloses the difficulties posed by this new reality. In Uber Belgium (Judgment Uber Belgium, 27 October 2016, case C-526/15), the national judge questioned the CJEU whether the principle of proportionality (established in article 5 TEU and Article 52(1) of the Charter of Fundamental Rights) in combination with Articles 15 to 17 of the Charter and 49 and 56 TFEU should be interpreted as precluding national legislation pursuant to which the notion of taxi service applies also to individual drivers that operate for free following requests by clients submitted through an electronic platform. The CJEU dismissed the case founding the reference inadmissible. It considered the question to be merely hypothetical - since the national legislation at stake did not seem to apply to services provided free of charge, and to contain a contradictory description of the activities at stake. ${ }^{19}$ Judgment Asociacion Profesional Elite Taxi, 20 December 2017, case C-434/15.
} 
related companies could be classified as unfair practices in breach of Spanish law, the court considered it necessary to ascertain whether or not Uber activities require prior administrative authorisation. The answer to that question would, however, depend on the classification of Uber services, notably whether the latter must be regarded as transport services, information society services or a combination of both. In this context, the national court decided to stay the proceedings and refer such question to the CJEU.

The preliminary reference at stake concerned merely that point of law. It was strictly a question on legal qualification, i.e. to know whether an intermediation service such as the one provided by Uber, the purpose of which is to connect, by means of a smartphone application and for remuneration, non-professional drivers using their own vehicle with persons who wish to make urban journeys, is to be classified as a "service in the field of transport" within the meaning of Article 58(1) of the Treaty on the Functioning of the European Union (TFEU) or whether, on the contrary, said service is covered by Article 56 TFEU, and Directives 2006/123 ${ }^{20}$ and 2000/31. ${ }^{21}$ Nonetheless, as seen below, the consequences of the correct legal classification go far beyond the application of the Internal Market rules.

In his Opinion, Advocate-General (AG) Szpunar considered at the outset that to answer that question, it was irrelevant to discuss the precise meaning of the term "collaborative economy", and whether Uber could be considered an example of a new way of pursuing economic activities. In his view, what is relevant is that Uber cannot be considered a ride-sharing platform since, in reality, it provides a traditional transport service: "whether or not it is to be regarded as forming part of a 'collaborative economy' is irrelevant to its classification under the law in force". ${ }^{22}$

According to the AG, and contrary to the company's allegations, Uber does not simply match supply to demand. It creates the supply itself, lays down rules concerning the essential characteristics of the supply and organises the way it works. ${ }^{23}$ In his analysis, the AG drew attention to the following aspects of the Uber business model:

a) Conditions applicable to the access and use of the platform by drivers: there are numerous terms and conditions governing the taking up and pursuit of the activity and also the conduct of drivers when providing services;

b) Conditions applicable to vehicles: although varying from country and city, as a rule, they must be four or five-door passenger vehicles subject, at least, to an age limit, and must have passed a roadworthiness inspection and comply with the provisions on mandatory insurance;

c) Conditions applicable to drivers: who must, at least, be in possession of a driving licence and have no criminal record;

d) Conditions applicable to the service and remuneration: drivers receiving a financial reward if they accumulate a large number of trips and Uber informing them of where and when they can rely on there being a high volume of trips and/or preferential fares;

e) Evaluation: as the application contains a rating function, enabling drivers to be

\footnotetext{
${ }^{20}$ Directive 2006/123 of the European Parliament and of the Council of 12 December 2006 on services in the internal market, OJ 2006 L 376, p. 36.

${ }^{21}$ Directive 2000/31 of the European Parliament and of the Council of 8 June 2000 on certain legal aspects of information society services, in particular electronic commerce, in the Internal Market, OJ 2000 L 178, p. 1.

${ }^{22}$ Para. 42 of the AG's Opinion.

${ }^{23}$ Cf. para. 43 of the AG's Opinion.
} 
evaluated by passengers and vice versa, an average score falling below a given threshold resulting in exclusion from the platform, especially for drivers;

f) Price: set by Uber through an algorithm and calculated based on the distance and duration of the trip, as recorded by the application by means of GPS. ${ }^{24}$

In this light, the AG concluded that Uber "exerts control over all the relevant aspects of an urban transport service". ${ }^{25}$ The other aspects associated with the company's activity are of secondary importance from the perspective of an average user of urban transport services and do not influence his economic choices. It is Uber who "controls the economically significant aspects of the transport service offered through its platform". ${ }^{26}$ At the level of legal qualification, this means that Uber's activity "comprises a single supply of transport" 27 in a vehicle located and booked by means of the smartphone application. According to the AG, this service is provided, from an economic standpoint, by Uber or on its behalf. This is also the way the service is presented to consumers and perceived by them, that when deciding to use Uber's services, look for a transport service offering certain functions and a particular standard of quality that are ultimately ensured by Uber itself.

In general, the Court of Justice agreed with the AG. It made, however, some important considerations. First, the Court highlighted that an intermediation service consisting of connecting a non-professional driver using his or her own vehicle with a person who wishes to make an urban journey is, in principle, a separate service from a transport service consisting of the physical act of transportation. The former service meets, in principle, the criteria for classification as an information society service.

However, the Court considered that the service rendered by Uber is more than such a service. While providing an intermediation service, Uber simultaneously offers urban transport services, which it makes accessible in particular through software tools such as its application, and whose general operation it organises for the benefit of persons who wish to accept that offer in order to make an urban journey. In this ambit, the Court accepted the AG's contention that Uber exercises decisive influence over the

\footnotetext{
${ }^{24}$ Cf. paras. 44-50 of the AG's Opinion.

${ }^{25}$ Para. 51 of the AG's Opinion.

${ }^{26}$ Ibidem. The AG distinguished Uber from intermediation platforms that allow for hotel reservations and flight purchases insofar as the latter operate independently from the hotels and airlines themselves: "[i]n contrast to the situation of Uber's drivers, both hotels and airlines are undertakings which function completely independently of any intermediary platform and for which such platforms are simply one of a number of ways of marketing their services. Furthermore, it is the hotels and airlines - and not the booking platforms - that determine the conditions under which their services are provided, starting with prices. These undertakings also operate in accordance with the rules specific to their sector of activity, so that booking platforms do not exert any prior control over access to the activity, as Uber does with its drivers" (para. 59). In Uber France (Judgment Uber France, 10 April 2018, case C-320/16), the same AG distinguished Uber from online advertising and franchising. The first, because it involves a service intended for users which consists in the communication of information: "[i]t [is] directed, principally at least, not at people who [are] already patients of the practitioner in question, but at the general public, in the hope of attracting new patients. That sort of communication may or may not result in the subsequent provision of dental services (and, probably, in most cases it will not). Although the advertising [is] without question closely connected with the dental practice as such, it [has], by contrast, no real connection with the actual dental care provided to individual patients". In the second case, because although "the franchisor may also exercise strict control over the activities of its franchisees, to the extent that customers will perceive the franchisees as branches of the franchisor rather than as independent undertakings ... the role of the franchisor is limited to providing services (such as trade mark licences, know-how, the supply of equipment and the provision of advice) to the franchisees. It will have no relationship with the users of the final services, which will be provided solely by the franchisees. The services of the franchisor are therefore independent of the final services, even if, in such a context, the franchisor determines the conditions under which those services are provided' (see paras. 18-22 of the AG's Opinion).

${ }^{27}$ Para. 53 of the AG's Opinion.
} 
conditions under which that service is provided, notably the maximum fare, the money flows, the quality of the vehicles, the drivers and their conduct.

Additionally, the Court highlighted two important dimensions associated with the provision of Uber's services based on the possible counterfactual scenario. In the Court's view, without Uber's application, Uber drivers would not be led to provide transport services, and persons wishing to make an urban journey would not use the services provided by those drivers. Thus, pursuant to the Court, the intermediation service provided by Uber is to be regarded as forming an integral part of an overall service whose main component is a transport service. ${ }^{28}$ This classification is said to be consistent with prior case-law of the Court, according to which the concept of "services in the field of transport" includes not only transport services in themselves but also any service inherently linked to any physical act of moving persons or goods from one place to another by means of transport. ${ }^{29}$

It has been argued that, from the Court's perspective, there are three important elements that need to be taken into account in the legal classification at stake: (i) that the services are part of the provision of other services; (ii) the market creation aspect; and (iii) the decisive influence by the platform over the conditions under which that service is provided. ${ }^{30}$ The two latter aspects seem to complement the first which seems to be the decisive one.

In any case, it should be noted that although not departing from the overall approach of the AG, the Court's conclusion is slightly different, insofar as it acknowledges that Uber provides a some-how two-sided service, an idea which hardly appears in the AG's Opinion. According to the Luxembourg judges, there is, nonetheless, one dimension of the service that is predominant with regard to the other, in such a way that in reality there is no mixed-service, but a single transport service. This approach echoes the socalled "centre of gravity" approach adopted by the Court in other fields of EU law. ${ }^{31}$

In this light, the Court goes beyond the AG's Opinion and concludes that Uber activities are covered not by Article 56 TFEU but by Article 58(1) TFEU. Freedom to provide services must, therefore, be achieved within the common transport policy [cf. Article 91(1) TFEU]. Given that in the current state of EU law, there are no common rules governing non-public urban transport services and services that are inherently linked to those services, it is for the Member States to regulate the conditions under which intermediation services such as the one rendered by Uber are to be provided (in conformity with the general rules of the TFEU). Consequently, the Court concluded that Uber type of activities fall entirely under national competence.

In reaching that conclusion, the CJEU makes clear that the question in Elite Taxi was more than a mere legal qualification issue, going to the heart of EU constitutional law. In deciding that Uber services fit into the common transport policy instead of the freedom to provide services, the CJEU was, in reality, adjudicating on

\footnotetext{
${ }^{28}$ Para. 40 of the judgment in Elite Taxi.

${ }^{29}$ Para. 41 of the judgment, mentioning to that effect, ruling in judgment Grupo Itevelesa and Others, 15 October 2015, case C168/14, paras. 45 and 46, and Opinion 2/15 (Free Trade Agreement with Singapore), 16 May 2017, para. 61.

${ }^{30}$ Lorna Woods, "Why Uber isn't Appy: the ECJ defines the difference between transport and digital services”, http:/ / eulawanalysis.blogspot.com/2017/12/why-uber-isnt-appy-ecj-defines.html.

${ }^{31}$ E.g., case-law on the correct legal basis: "[i]f examination of a measure reveals that it pursues a twofold aim or that it has a twofold component and if one of those is identifiable as the main one, whereas the other is merely incidental, the measure must be based on a single legal basis, namely that required by the main aim or component". See e.g., judgment Commission/Council, 11 September 2003, case C-211/01, para. 39.
} 
a fundamental constitutional issue: the limits of conferral and the exact scope of the Union's competences to act on the subject matter at stake. The debate on the correct classification of services provided within the new collaborative economy became essentially a discussion on the principle governing the division of competences between the Union and the States.

In addition, one should not underestimate the possible "slippery slope" effect of the CJEU's judgment. The qualification of Uber as a carriage may have an important impact at numerous levels, notably on issues of taxation, Regulation and Competition law. Two examples can be referred to here in the field of Competition law.

On the one hand, in considering that Uber provides a transport service, the CJEU may have contributed to blur the waters with regards to the understanding of the market for Competition law purposes. In this respect, authors have hesitated in the legal qualification of Uber drivers as employees or independent contractors. ${ }^{32}$ In Elite Taxi, the AG disregarded the relevance of this distinction since, in his view, a transport company may very well provide its services either through independent traders or through its employees. ${ }^{33}$ According to the AG, the fact that Uber is not the owner of the vehicles is also irrelevant in this regard. Nonetheless, although it is far from obvious if drivers can be considered as Uber subcontractors, these considerations lead us to revisit well-established concepts of Competition law, such as the notion of an undertaking or single economic entity. ${ }^{34}$ The issue of knowing whether Uber and Uber drivers should be considered as separate economic entities is indeed problematic. The question arises subtly in the AG's understanding according to whom Uber drivers do not pursue an activity that exists independently of the platform. On the contrary, the activity exists solely because of the platform, without which it would have no sense. However, contrary to what has been generally considered, ${ }^{35}$ the $A G$ also made clear that the said relationship does not necessarily need to be perceived as a pure labour relationship. It seems that we are left in a grey area between labour relations, agency and other contractual arrangements, without being clear in which box to put Uber.

Moreover, this statement by the AG - which echoes the Court's approach to the counterfactual, i.e., that in the absence of Uber, neither the drivers nor the consumers would use the service - in combination with the idea that Uber provides a transport service, raises a second line of questions dealing with a well-known topic of Competition law: the definition of the relevant market. ${ }^{36}$ If one assumes that Uber provides a transport service, it should be possible to affirm that it is present in the same

\footnotetext{
${ }^{32}$ See e.g., Julian Nowag, "The Uber Cartel?”, 3 ss.

${ }^{33}$ The issue has been widely discussed in US Courts. Uber lost a high profile case in California where it was found to be an employer due to the control exerted over the driver. While Uber lost a similar case in Florida and appealed both the California and Florida cases, it was successful in claiming that drivers are independent contractors in Georgia, Pennsylvania and Texas. See e.g., Julian Nowag, "The Uber Cartel?", 3.

${ }^{34}$ In the EU, Uber could potentially also argue that the arrangement with its drivers is based on an agency agreement, which are typically not subject to EU competition law due to the single economic entity doctrine. To that effect, Uber would need to establish that the drivers bear no or only an insignificant financial or commercial risk of the transactions with the customers which would not be unproblematic. See Nowag, The Uber Cartel..., 7.

${ }^{35}$ See for further discussion, Victoria Daskalova, "Regulating the new self-employed in the Uber economy: What Role for EU Competition Law?," TILEC Discussion Paper No. 2017-028, https:// papers.ssrn.com/sol3/papers.cfm?abstract_id=3009120.

${ }^{36}$ Commission notice on the definition of the relevant market for the purposes of Community competition law, OJ C 372, 9.12.1997, p. 5-13.
} 
market as taxi drivers/companies. However, this conclusion is not as straightforward as it may seem at first. Supporting this view, the Portuguese Competition Authority, in a report from 2016, ${ }^{37}$ considered that the carriage of people in passenger vehicles comprises different types of services, notably (i) taxi operators, (ii) car rentals with a driver and (iii) other transportation services usually associated with tourism. ${ }^{38}$ The Authority argued that electronic platforms represent relevant opportunities, notably at the level of efficiencies and competition, mitigating possible market failures and other public policy concerns which have, until now, justified strong public regulation. It its report, the Authority seems to consider that Uber and taxis are present in the same relevant market, insofar as the emergence of transport services based on electronic platforms made clear the consequences for competition of the current strict regulatory framework, bringing to light the need to reform the sector. Notably, in the Authority's words, the option to ban these new business models would have the potential of not only depriving consumers of the benefits of innovation but also, of the "competitive pressure ${ }^{\text {'39 }}$ exercised on traditional taxi operators.

Following this line of reasoning, Italian courts have also decided that Uber cannot be qualified as a pure "match maker" insofar as UberPop allows drivers to sell transportation services to potential customers for profit. In this relationship, Uber does not play a secondary role because as drivers, they are not free to negotiate prices with passengers. The price is fixed by Uber's algorithm that adjusts the tariffs according to supply and demand. Thus, Italian courts considered it to be; "undisputable that the market covered by Uber is exactly the same as that covered by taxis: the individual public transportation market where the customers' needs can be satisfied equally by either a taxi booked by radio service or by private cars booked by UberPop". ${ }^{40}$

By contrast, in the United States of America, in a case decided by the Seventh Circuit Court on the legitimacy of an ordinance of Chicago City applying specific rules to transportation network providers, the court considered that the different rules applied to the latter were justified by the fact that their services are different and not interchangeable with taxi services ${ }^{41}$. According to the court, the major difference is that, in order to use Uber services, customers must sign up with a mobile application, thereby creating a contractual relationship with specific terms (such as fares, driver qualifications, insurance), so that the passenger knows these elements in advance.

\footnotetext{
${ }^{37}$ In July 2016, the Portuguese Competition Authority launched a public consultation paper on the issues of competition and regulation in the sector of transport in passenger vehicles, in Portugal. The consultation period ended in September, and on December $28^{\text {th }}$, the Authority issued its final report on the matter, where it identified the main regulatory constraints and presented a set of recommendations to improve competition in the market. A few days earlier, the Government approved the draft bill, to be submitted to Parliament, establishing the new legal regime on Transport in Ordinary Vehicles through Electronic Platforms (Proposta de Lei n. ${ }^{\circ}$ 50/XIII).

${ }^{38}$ In Portugal, these activities are currently subject to significant regulatory constraints, mostly in what regards taxi services. According to the legislation in force, public transportation is subject to strict licensing requirements. The Competition Authority has identified restrictions to competition at the level of market entry, prices, quality and safety standards and other regulatory requirements.

39 See "Relatório sobre Concorrência e Regulação no Transporte de Passageiros em Veículos Ligeiros", December 2016, available at: http://www.concorrencia.pt/vPT/Noticias_Eventos/ ConsultasPublicas/Documents / Relat $\% \mathrm{C} 3 \% \mathrm{~B} 3$ rio $\% 20$ sobre $\% 20$ Concorr $\%$ C $3 \%$ AAncia $\% 20$ e $\% 20$ Regula $\%$ C3\%A7\%C3\%A3o\%20no $\% 20$ Transporte $\% 20 \mathrm{de} \% 20$ Passageiros $\% 20$ em $\% 20$ $\mathrm{Ve} \% \mathrm{C} 3 \%$ ADculos $\% 20$ Ligeiros.pdf.

${ }^{40}$ Alessio di Amato, "Uber and the Sharing Economy", 178.

${ }^{41}$ Illinois Transportation Trade Association v City of Chicago, Nos. 16-2009, 7 October, 2016.
} 
Differently, taxis are allowed to take on persons who hail them on the street, which means that an ordinance aimed at protecting passengers by screening the drivers and by imposing a uniform system of rates is justified.

The previous cases disclose two different views regarding the interchangeable nature of the services provided by Uber and taxi drivers, which is pivotal to determine the relevant market for Competition law purposes. To these difficulties, one can add a further layer of complexity. In fact, assuming that Uber provides a transport service, how should one conceive the activities developed by associated companies of Uber who exploit numerous vehicles and employ several drivers to that effect? What is there to say about individual Uber drivers themselves, who may provide transport services on several platforms who are Uber's competitors? Moreover, if one accepts the AG's idea that Uber created a new form of supply which was not pre-existent, must companies such as the Portuguese Mytaxi that allows users to book and order taxis through a mobile application - be considered as operating in a different market? What is ultimately the difference, from an economic and legal standpoint, between the activities pursued by all those involved in the provision of transport services through electronic platforms? ?2 $^{42}$

\section{Uber and regulation: technical rules and duty of prior notification}

The preliminary reference made by the Lille court resulted in the judgment in Uber France, ${ }^{43}$ where the CJEU faced a variant of the question decided in Elite Taxi. In this case, a French court had to decide on several offences allegedly committed by Uber France, notably (i) misleading commercial practices, (ii) the aiding and abetting of the unlawful exercise of the profession of taxi driver, and (iii) the unlawful organization of a system for putting customers in contact with persons carrying passengers by road for remuneration using vehicles with fewer than 10 seats. With regard to the latter offense, the national court was uncertain as to whether the provision included in the French Code of Transports should be regarded as establishing a "rule on information society services" within the meaning of Article 1(5) of Directive $98 / 34 .{ }^{44}$ In the affirmative, said provision would be subject to the duty of prior notification to the European Commission before its adoption and the lack of said notification meant that it could not be enforced against individuals. However, that would not be so if, on the contrary, the rule was to be considered as governing "services in the field of transport" within the meaning of Article 2(2)(d) of Directive 2006/123. Hence, although from a different perspective, the question referred to the CJEU was not far from the one decided in Elite Taxi.

The provision of national law at stake corresponded to Article L. 3124-13 of

\footnotetext{
${ }^{42}$ From an antitrust standpoint, several other questions can be explored in face of the CJEU's judgment in Elite Taxi. Scholars have questioned whether the Uber business model may entail a "hub and spoke" cartel, whether it involves illegal price fixing, and whether regulation can be achieved merely my applying Articles 101 and 102 TFEU.

${ }^{43}$ Judgment Uber France, 10 April 2018, case C-320/16.

${ }^{44}$ Directive 98/34 of the European Parliament and of the Council of 22 June 1998 laying down a procedure for the provision of information in the field of technical standards and regulations was meanwhile ssuperseded by Directive 2015/1535 of the European Parliament and of the Council of 9 September 2015 laying down a procedure for the provision of information in the field of technical regulations and of rules on Information Society services.
} 
the Transport Code, which laid down criminal penalties for the organisation of a system for putting customers in contact with persons carrying passengers by road for remuneration using vehicles with fewer than 10 seats, without being authorised to do so. Based on the precedent, the CJEU recalled that the intermediation service at issue was to be regarded as forming an integral part of an overall service, the main component of which was a transport service and, accordingly, had to be classified as a service in the field of transport. In this light, insofar as the national court concluded that the intermediation service at stake did not essentially differ from the service in Elite Taxi, legislation that provided for criminal proceedings against a company rendering said intermediation service could not come within the scope of Directive 2006/123. ${ }^{45}$

It must be noted that in Uber France the Court mixed up the legal qualification of the service itself with the classification of the norm applicable to its provision. The AG carried out a finer analysis, considering that even if the CJEU were to find that the UberPop service was an information society service, that would not affect the classification of the provision of the French law in question as a technical regulation. Indeed, not every provision that concerns, in one way or another, information society services automatically falls within the category of technical regulations. In this context, although not ignoring that the prohibition at stake, it was principally directed at systems that connect two parties by electronic means and therefore, are aimed at information society services even if it could theoretically affect other categories of intermediaries in the field of transport, the AG highlighted that a rule on services is a requirement of a general nature relating to the taking-up and pursuit of service activities. Also, in order to be classified as a technical regulation, it is necessary that the specific aim and object of such a requirement is to regulate such services in an explicit and targeted manner. ${ }^{46}$ By contrast, rules which affect such services only in an implicit or incidental manner are excluded from the duty of notification. It was clear that the purpose of the French provision was not to prohibit or to regulate the activity of putting customers in touch with providers of transport services in general. It was solely to prohibit and to punish the activity of intermediary in the illegal exercise of transport activities. Therefore, the activity of intermediary in legal transport services remains entirely outside the scope of the provision. That being so, the provision affects information society services only in an incidental manner. According to the AG, the regulatory contribution made by the prohibition lies principally in the establishment of criminal sanctions for participation in an activity which is already illegal under national legislation. These provisions are not and must not be subject to prior notification to the European Commission. An excessive notification obligation, with the penalty of regulations that have not been notified being inapplicable, would facilitate circumvention of the law and engender legal uncertainty, including in relationships between individuals. ${ }^{47}$

The contrast between the approaches of the Court and of the AG in Uber France can be tested with the Portuguese example. Indeed, it is unclear where to draw the line with regard to the duty of notification in respect of the recently adopted legislation governing individual transport in ordinary vehicles based on electronic platforms ${ }^{48}$ The bill draws on a fundamental distinction between the types of services

\footnotetext{
${ }^{45}$ Paras. $22-26$ of the judgment.

${ }^{46}$ Para. 24 of the AG's Opinion.

${ }^{47}$ Para. 31 of the AG's Opinion.

${ }^{48}$ Law No. 45/2018, of $10^{\text {th }}$ August. The new Act was the result of hard and long negotiations with
} 
provided by the new market players. On the one hand, it establishes the specific obligations applicable to the operators providing directly for transport services, foreseeing, for example, (i) qualification requirements for drivers; (ii) specific features and identification obligations applicable to vehicles; (iii) mandatory insurances; (iv) prohibition to take on passengers on the street and use bus lanes; (v) limitations on work hours, among others. On the other hand, the bill defines the conditions applicable to the companies providing for electronic platforms which organize and intermediate transportation services. In this respect, the bill includes rules governing not only access to the activity itself but also imposing precise duties to provide information to customers with regard, notably, to the services, prices, maps, rating system, identification of drivers and vehicles. The distinction between the legal regime applicable to the platforms and the one applicable to the drivers goes against the trend endorsed by the European case-law and may create paradoxical results. As a matter of fact, it could be argued that although Uber should be considered as rendering transportation services, the rules governing its activity must be considered as information society rules for purposes of prior notification to the European Commission. In fact, to borrow the AG's words, the new set of rules applicable to electronic platforms organizing transport services in Portugal clearly regulate the taking-up and pursuit of such activities, having "the specific aim and object the regulation of such services in an explicit and targeted manner". ${ }^{49}$

\section{Concluding remarks}

Let us end with three brief final remarks. First, to question whether the approach of the CJEU in the Uber cases can be reconciled with the position of the European Commission in the above-mentioned European Agenda for the Collaborative Economy. Indeed, the Commission has called upon States to take the opportunity created by the emergence of new business models to simplify and modernize the conditions governing access to the market, loosening unnecessary regulatory constraints and avoiding market fragmentation. In contrast, by acknowledging the strictly national competence to regulate Uber (and alike) activities, the CJEU may have taken a step in the opposite direction. Emblematically, in Portugal, the national legislator seized the moment not to reform the taxi sector - as suggested also by the national Competition Authority ${ }^{50}$ - but to introduce a new sophisticated regulatory framework applicable to the companies and drivers rendering transport services based on electronic platforms.

This approach contrasts also with the expansion of Uber's activities and the overwhelming reaction by consumers to the new opportunities created by the so-called sharing economy. There is a strong consumer movement supporting Uber, questioning the privileges of incumbent taxi operators and demanding free competition. The fact that Uber has become an important source of income for

the stakeholders. It was drafted with the aim of regulating services already available to consumers, but which are legally distinguished from taxi services. Contrary to ordinary vehicles, taxis are considered to address specific market failures and are therefore subject to public service obligations.

${ }^{49}$ Para. 24 of the AG's Opinion in Judgment Uber France, 10 April 2018, case C-320/16.

50 The Portuguese Competition Authority highlighted the need to undertake a regulatory reform which should not, in any case, result in replicating the existing regulatory framework to new entrants but, on the contrary, in loosening current rules in order to ensure more competition and promote a broader supply range and higher quality of services. 
the unemployed and that it represents an alternative to the purchase of private cars is certainly not irrelevant. For what is worth, one must bear in mind that, in this context, consumer choices must not be underestimated. It is clear that the future of the sharing economy will largely depend on consumer behaviour.

Secondly, to draw attention to the preliminary reference made by the German court in Uber $B V V^{51}$ which leaves an important question open regarding Member State's intervention in the field of transport. Having also dwelled on the exact legal classification of Uber activities, the Bundesgerichtshof questioned the CJEU on whether it would be possible to justify a ban on Uber activities based on public order considerations. In this respect, it is worthwhile to remember that the CJEU has acknowledged a significant margin of discretion to Member States when derogating from Treaties for public order reasons. More significantly, the question brings to the table, in a clearer fashion, the need to find the adequate balance between the Union and the States' competences on transport issues. In this respect, one may wonder whether there is room under the Treaties for full harmonization in this field, and if Articles 114 and 352 TFEU could be used as alternative or complementary legal basis to Article 91 TFEU.

Lastly, drawing on the previous points and going back to where I started, despite the anxieties and hesitations brought by the emergence of new technologies, the debate surrounding the innovative models of the sharing economy teaches us that, nine times out of ten, it is not necessary to reinvent the wheel. Much of the legal questions put by the new realities are, in fact, old questions that have long been discussed in the context of equally old inventions. This is not to say that all problems of humankind have already been sorted out. It is, however, to acknowledge that, very often, the instruments necessary to deal with new phenomena are well-known. Thus, let us not forget that much of the solutions the future demands are present in the formulas that have always governed human action, at least inasmuch we aim to construe a just, prosperous and harmonious society.

${ }^{51}$ Judgment Uber BV , Case C-371/17, Removed from the register on 12 April 2018. 